\title{
In vitro plant regeneration system for date palm (Phoenix dactylifera L.): effect of chelated iron sources
}

\author{
Ahmed Madi Waheed Al-Mayahi@
}

\begin{abstract}
Background: Iron chelate sources and their concentrations are important factors in in vitro propagation of date palm. This study's objective was to investigate the effect of the iron chelated form on the growth and development of tissue cultures of Barhee cultivar.

Results: The addition of FeEDDHA to the culture medium was more effective than FeEDTA on callus growth, shoot regeneration, and the number of shoots per jar, where the best result (220.8mg callus, $86.67 \%$ and 17.2 shoots per jar, respectively) was obtained by using $93.5 \mathrm{mg} \mathrm{L}^{-1} \mathrm{FeEDDHA}\left(5.6 \mathrm{mg} \mathrm{L}^{-1} \mathrm{Fe}\right)$, compared with other treatments. The results also indicate that using $93.5 \mathrm{mg} \mathrm{L}^{-1}$ FeEDDHA $\left(5.6 \mathrm{mg} \mathrm{L}^{-1} \mathrm{Fe}\right)$ as a supplement can decrease antioxidant enzymes CAT and POD activity compared to the rest of the treatments. Medium equipped with 187.0 $\mathrm{mg} \mathrm{L}^{-1}$ FeEDDHA (11.2 $\left.\mathrm{mg} \mathrm{L}^{-1} \mathrm{Fe}\right)$ had the highest rooting percentage and number of roots per shoot than other treatments. The biochemical analysis results showed that treatments with FeEDDHA of $280.5 \mathrm{mg} \mathrm{L}^{-1}\left(16.8 \mathrm{mg} \mathrm{L}^{-1}\right.$ $\mathrm{Fe})$ and $187.0 \mathrm{mg} \mathrm{L}^{-1}\left(11.2 \mathrm{mg} \mathrm{L}^{-1} \mathrm{Fe}\right)$ significantly increased the iron content. The results showed that shoot maximum chlorophyll and endogenous IAA level content were recorded in a medium supplemented with 187.0 $\mathrm{mg} \mathrm{L}^{-1}$ FeEDDHA (11.2 $\left.\mathrm{mg} \mathrm{L}^{-1} \mathrm{Fe}\right)$ as Fe source.
\end{abstract}

Conclusion: FeEDDHA used in the present study was proven to be a promising iron chelate source in comparison with the FeEDTA sources.

Keywords: Iron chelate, Shoot regeneration, Antioxidant enzymes, Indole acetic acid (IAA), Rooting

\section{Background}

Micropropagation is a promising way for obtaining large amounts of uniform plants that are disease-free and without pests during plant material exchange, genetically identical, and high-quality planting material. The increasing demand for rare and excellent quality date palm cultivars makes us use micropropagation as an unavoidable propagation method [1-3]. Plant tissue culture success as a plant propagation method is greatly influenced by the growth media composition [4-6]. Among the micronutrients is iron element. It is an essential element of plant tissue culture media; it is necessary for plant

Correspondence: hng_1988@yahoo.com

Date Palm Research Centre, University of Basrah, Basrah, Iraq growth and chlorophyll production. Iron $(\mathrm{Fe})$ is critical for many physiological activities like chlorophyll synthesis and biochemical reactions, photosynthesis, respiration, and enzyme activity [7]. This element is involved in the chemical composition of major molecules such as metal-containing enzymes, the Fe-sulfur cluster, the heme, and other Fe-binding sites [8]. To avoid Fe deficiency or toxicity, plants have developed mechanisms to maintain homeostasis by regulating the intake, use, and storage of Fe, depending on its availability for the media [9]. Since Fe is not soluble, particularly in aerobic and high $\mathrm{pH}$ conditions, it is rarely accessible to plants. Therefore, it is used more effectively in a Fe chelate form [9]. In in vitro culture conditions, iron is a part of a balanced culture medium that is chemically fixed. Iron 
is supplied in MS medium [10] as a chelated component of ferric ethylenediaminetetraacetic acid (FeEDTA). This is not a stable form, and Fe released soon becomes unavailable to tissues cultured due to iron-phosphate formation [11]. Iron deficiency or altered $\mathrm{pH}$ of the culture medium leads to decreased availability, bud growth inhibition, and reduced chloroplast pigments [12].

Ethylenediamine di-2-hydroxyphenyl acetate ferric (FeEDDHA), due to its high stability and high $\mathrm{pH}$ solubility, is the most efficient and used Fe chelates. Commercial FeEDDHA synthesis usually produces multiple position isomers by-products. Replacing ferric ethylenediaminetetraacetic acid (FeEDTA) with an equivalent amount of FeEDDHA had an encouraging effect on micropropagation. Also, FeEDDHA increased the ability to multiply axillary shoots and regenerate adventitious shoots, and induction of roots in the culture medium [13] indicated that the addition of FeEDDHA to the culture medium increased the chlorophyll content compared to FeEDTA. Research on the effect of Fe source on date palm micropropagation is somewhat limited. Therefore, the purpose of this study was to optimize in vitro propagation technique of date palm cv. Barhee, by studying the effect of the chelated form of the iron salt of ferric ethylene di-2-hydroxyphenyl acetate (FeEDDHA) and iron-ethylene diamine-tetracyclic acid (FeEDTA) on callus growth, in vitro regeneration and rooting of shoots, and some of the biochemical parameters.

\section{Methods}

\section{Plant materials and treatments}

The apical buds were sectioned longitudinally into four sections. In order to induce callus formation, explants were transferred to MS basal medium [10] supplemented with $3 \mathrm{mg} \mathrm{L}^{-1}$ 6-(dimethylallyl amino) purine (2iP), $30 \mathrm{mg}$ $\mathrm{L}^{-1}$ naphthalene acetic acid (NAA), $1.5 \mathrm{~g} \mathrm{~L}^{-1}$ activated charcoal, and solidified with Agar-Agar at $7.0 \mathrm{~g} \mathrm{~L}^{-1}$. Cultures were kept under complete darkness at $27 \pm 2{ }^{\circ} \mathrm{C}$. The cultures were transferred to fresh media, with the same composition after every 6 weeks interval until the callus had initiated. For callus propagation, it was transferred and grown in jars containing $25 \mathrm{ml}$ of the MS medium, equipped with $100 \mathrm{mg} \mathrm{L}^{-1}$ glutamine, $5 \mathrm{mg} \mathrm{L}^{-1}$ thiamine $\mathrm{HCl}, 1 \mathrm{mg} \mathrm{L}^{-1}$ biotin, $30 \mathrm{~g} \mathrm{~L}^{-1}$ sucrose, and solidified with agar at $7.0 \mathrm{~g} \mathrm{~L}^{-1}$ and $0.5 \mathrm{~g} \mathrm{~L}^{-1}$ activated charcoal, with the addition of NAA at $6 \mathrm{mg} \mathrm{L}^{-1}$ and $2 \mathrm{iP}$ at 2 $\mathrm{mg} \mathrm{L}^{-1}$. Two $\mathrm{Fe}$ forms were included in the medium [FeEDTA (ferric ethylenediaminetetraacetic acid) and FeEDDHA (ethylenediamine di-2-hydroxyphenyl acetate ferric)]. The supplementation of iron sources at different concentrations in the growth medium was assessed. MS medium was modified at two concentrations of FeEDTA [(T1) $36.7 \mathrm{mg} \mathrm{L}^{-1}$ (5.6 mg L${ }^{-1} \mathrm{Fe}$ ) (control), and (T2) 73.4 $\left.\mathrm{mg} \mathrm{L}^{-1}\left(11.2 \mathrm{mg} \mathrm{L}^{-1} \mathrm{Fe}\right)\right]$ or three concentrations of FeEDDHA [(T3) $93.5 \mathrm{mg} \mathrm{L}^{-1}$ (5.6 $\mathrm{mg} \mathrm{L}^{-1} \mathrm{Fe}$ ), (T4) $187.0 \mathrm{mg}$ $\mathrm{L}^{-1}\left(11.2 \mathrm{mg} \mathrm{L}^{-1} \mathrm{Fe}\right)$, and (T5) $280.5 \mathrm{mg} \mathrm{L}^{-1}\left(16.8 \mathrm{mg} \mathrm{L}^{-1}\right.$ $\mathrm{Fe})]$. The $\mathrm{pH}$ of the medium was adjusted to $5.7-5.8$ before the addition of agar. Media dispensed into culture containers. All culture containers with media were autoclaved at $121^{\circ} \mathrm{C}$ and $1.04 \mathrm{~kg} . \mathrm{cm}^{-2}$ for $20 \mathrm{~min}$. Cultures were incubated in the culture room at $27 \pm 2{ }^{\circ} \mathrm{C}$ and irradiated for $16 \mathrm{~h}$ with a diffuse light provided by cool white fluorescent lamps $\left(\mu \mathrm{mol} \mathrm{m} \mathrm{m}^{-2} \mathrm{~s}^{-1}\right)$. The weight of the callus was recorded after 6 weeks from culturing. For multiplication, the callus was divided and subcultured on regeneration media equipped as mentioned above, except for the plant growth regulators $1 \mathrm{mg} \mathrm{L}^{-1}$ (NAA) and $3.0 \mathrm{mg} \mathrm{L}^{-1}$ (2iP) [14]. It was also equipped with the same FeEDDHA and FeEDTA concentrations to study their effects on bud multiplication, and some changes in phytochemical traits are mentioned below. Cultures were incubated in the growth chamber at $25 \pm 2^{\circ} \mathrm{C}$ under $16 \mathrm{~h}$ photoperiods. The experiments regarding the percentage of bud induction and bud number per jar were recorded after 12 weeks of culturing callus on the multiplication media.

Catalase activity (CAT, EC 1.11.1.6) was assayed, according to [15]. CAT has been verified in the $1 \mathrm{M}$ of $\mathrm{H}_{2} \mathrm{O}_{2} \mathrm{~g}^{-1} \mathrm{FW}$ min $^{-1}$; the activity of the enzyme has been evaluated at $25 \pm 2{ }^{\circ} \mathrm{C}$. The total $3 \mathrm{~mL}$ solution mixture was $2.8 \mathrm{~mL}(25 \mathrm{mM}, \mathrm{pH} 7.0), 0.1 \mathrm{~mL}$ enzyme extract, and $0.1 \mathrm{~mL}(0.4 \%)$. H $2.8 \mathrm{~mL}$ phosphate buffer. Upon adding $\mathrm{H}_{2} \mathrm{O}_{2}$, the reaction began. The decline of $\mathrm{H}_{2} \mathrm{O}_{2}$ inhibition depends on the regulation of absorbance reduction at $240 \mathrm{~nm}$.

\section{Estimation of peroxidase activity (POD)}

Shootlet enzyme extract was prepared as recommended by [16]. The leaf tissues have been grounded with $0.1 \mathrm{M}$ sodium phosphate buffer at $\mathrm{pH} 7.1$ (2 ml buffer/g of fresh tissue in a mortar). These triturated tissues have been strained through four layers of cheesecloth, and the filtrates were centrifuged at $3000 \mathrm{rpm}$ for $20 \mathrm{~min}$ at 6 ${ }^{\circ} \mathrm{C}$. For an estimate, the enzyme of the supernatant fluid was used. The activity of peroxidase was calculated by the methods of [17].

\section{Effect of FeEDDHA and FeEDTA on in vitro rooting}

Clusters of unrooted in vitro shoots of date palm $\mathrm{cv}$. Barhee were collected in the elongation stage. Typical shoots were separated individually and cultured on MS medium [10]. The culture media consisted of MS salts, supplemented with $30 \mathrm{mg} \mathrm{L}^{-1}$ sucrose, $0.5 \mathrm{mg} \mathrm{L}^{-1} \mathrm{NAA}$, and $0.5 \mathrm{~g} \mathrm{~L}^{-1}$ activated charcoal, $7 \mathrm{mg} \mathrm{L}^{-1}$ agar, and different concentrations of FeEDTA (0, 50, 75, and $150 \mathrm{mg}$ $\left.\mathrm{L}^{-1}\right)$ or FeEDDHA $\left(0,0.5,2.5\right.$, and $\left.5.0 \mathrm{mg} \mathrm{L}^{-1}\right)$. The $\mathrm{pH}$ was adjusted to $5.7-5.8$, and then, the media were autoclaved at $121^{\circ} \mathrm{C}$ for $20 \mathrm{~min}$. All cultures were incubated 
under room temperature $25 \pm 2{ }^{\circ} \mathrm{C}$, with a $16 \mathrm{~h}$ photoperiod provided by white florescent light. The experiment results regarding the percentage of root induction and root number per shoot were evaluated 6 weeks after the inoculation of shoots on the culture media.

\section{Mineral analysis of shoots}

Elemental analysis was performed on content of potassium $(\mathrm{K})$, calcium $(\mathrm{Ca})$, and boron $(\mathrm{B})$ in date palm shoots after 12 weeks of culture according to the method described by [18]. Before the analysis, the shoots were separated and washed with deionized water twice and dried at $60^{\circ} \mathrm{C}$ until reaching constant weight. Dried shoots $(0.5 \mathrm{~g})$ were digested with a mixture of sulfuricperchloric acid under heating for $1 \mathrm{~h}$. The digested solution was transferred into volumetric flask $50 \mathrm{~cm}^{3}$, and volumes were completed in size with distilled water. The extract of the samples was filtered and diluted to the volume of $50 \mathrm{ml}$. Ca and $\mathrm{Mg}$ content was determined by flame atomic absorption spectrophotometry. A UVvisible spectrophotometer measured the absorbance of the solution at a wavelength of $620 \mathrm{~nm}$ [19]. For B analysis, dried shoots were ash dried $\left(60{ }^{\circ} \mathrm{C}\right.$ for $\left.1 \mathrm{~h}\right)$ and digested with $10 \mathrm{ml} 0.36 \mathrm{~N} \mathrm{H}_{2} \mathrm{SO}_{4}$ [20]. B was quantified by a spectrometer. There were three replicates of each treatment. The atomic absorption spectrophotometer determined the shoot samples' iron content at the wave length of $324.8 \mathrm{~nm}$.

\section{Assessment of chlorophyll content}

The chlorophyll content in the leaves was measured using the method of [21].

\section{Extraction and measurement of auxins}

Auxins were extracted and quantified according to [22]. Five grams of leaves after various treatments with FeEDDHA and FeEDTA were homogenized using 80\% methanol. The extract has been filtered through the Whatman filter paper (no. 1) and evaporated at $4{ }^{\circ} \mathrm{C}$ in dark conditions under a vacuum. The supernatant was dried in a vacuum, withdrawn by a $0.1 \mathrm{M}$ phosphate potassium ( $\mathrm{pH}$ 8.1). Eleuate was obtained by using $1 \mathrm{~N}$ hydrochloric acid $(\mathrm{HCI})$ and by using a partitioning $(4 \mathrm{x})$ with diethyl ether, in dryness, in water with a $\mathrm{pH}$ set to 2.5. The injection in reversed HPLC, C18 column, in the isocratic elution mode by the concentrate, determined phytohormones using a portable acetone step (26:74) with $30 \mathrm{mM}$ of phosphoric acids. A UV detector (2996 PDA detector) with $280 \mathrm{~nm}$ was passed through the column eluants, and auxins were detected and quantified. Standard auxins were used as the source (IAA).

\section{Experimental design and statistical analysis}

The data were statistically analyzed by one-way analysis of variance (ANOVA) using statistical analyses with the SPSS packet software. Separation of means among treatments was determined using L.S.D. test at $5 \%$.

\section{Results}

The results from the present study indicate that the callus tissues grown at FeEDDHA $\left(93.5 \mathrm{mg} \mathrm{L}^{-1}\right)(5.6 \mathrm{mg}$ $\mathrm{L}^{-1} \mathrm{Fe}$ ) showed better growth (220.8 $\mathrm{mg} 100 / \mathrm{mg}$ callus) (Table 1) followed by a high induction of buds with the highest average of shoot formation (Fig. 2, T3), which were $86.67 \%, 17.2$ shoots, respectively. On the other hand, callus weight, shoot multiplication, and average shoot formation significantly decreased at double FeEDTA and triple FeEDDHA concentration in MS medium (Table 1, Figs. 1 and 2, T2 and T5).

\section{The activity of catalase (CAT) and peroxidase (POD)}

The highest CAT and POD were obtained when callus was cultured in the medium supplied with a high concentration of FeEDDHA $280.5 \mathrm{mg} \mathrm{L}^{-1}\left(16.8 \mathrm{mg} \mathrm{L}^{-1} \mathrm{Fe}\right)$ (Fig. 3, T5), significantly different from the other treatments. Simultaneously, the least CAT and POD activity of the shoots was achieved in the medium supplied with $93.5 \mathrm{mg} \mathrm{L}^{-1}$ FeEDDHA (5.6 $\mathrm{mg} \mathrm{L}^{-1} \mathrm{Fe}$ ) (Fig. 3A and B).

\section{Effect of Fe sources on the rooting formation}

According to the results obtained in Fig. 1 (Table 2), increasing FeEDDHA concentration of the medium from $93.5\left(5.6 \mathrm{mg} \mathrm{L}^{-1} \mathrm{Fe}\right)$ to $187.0 \mathrm{mg} \mathrm{L}^{-1}\left(11.2 \mathrm{mg} \mathrm{L}^{-1} \mathrm{Fe}\right)$ resulted in a percentage of rooting increasing and the number of roots. The result was different from FeEDTA when its concentration was increased from 36.7 (control)

Table 1 Effect of chelated iron sources on callus growth, a response percentage (\%) of callus for bud formation, and the number of buds

\begin{tabular}{llll}
\hline Treatments $\left(\mathrm{mg.L}^{-1}\right)$ & Callus growth & Response of callus for buds regeneration (\%) & Mean number of buds/100 mg \\
\hline T1 (control) & $198.2 \pm 1.79 \mathrm{~b}$ & $66.67 \pm 3.05 \mathrm{c}$ & $12.2 \pm 0.25 \mathrm{~b}$ \\
T2 & $141.0 \pm 3.60 \mathrm{c}$ & $53.34 \pm 2.60 \mathrm{~d}$ & $7.6 \pm 0.38 \mathrm{c}$ \\
T3 & $220.8 \pm 2.21 \mathrm{a}$ & $86.67 \pm 6.88 \mathrm{a}$ & $17.2 \pm 0.83 \mathrm{a}$ \\
T4 & $187.0 \pm 2.05 \mathrm{~b}$ & $73.34 \pm 4.81 \mathrm{bc}$ & $10.0 \pm 0.38 \mathrm{~b}$ \\
T5 & $116.4 \pm 2.44 \mathrm{~d}$ & $46.67 \pm 4.70 \mathrm{~d}$ & $6.0 \pm 0.21 \mathrm{c}$
\end{tabular}

Means in each column with different letters show significant differences $(P \leq 0.05)$ 


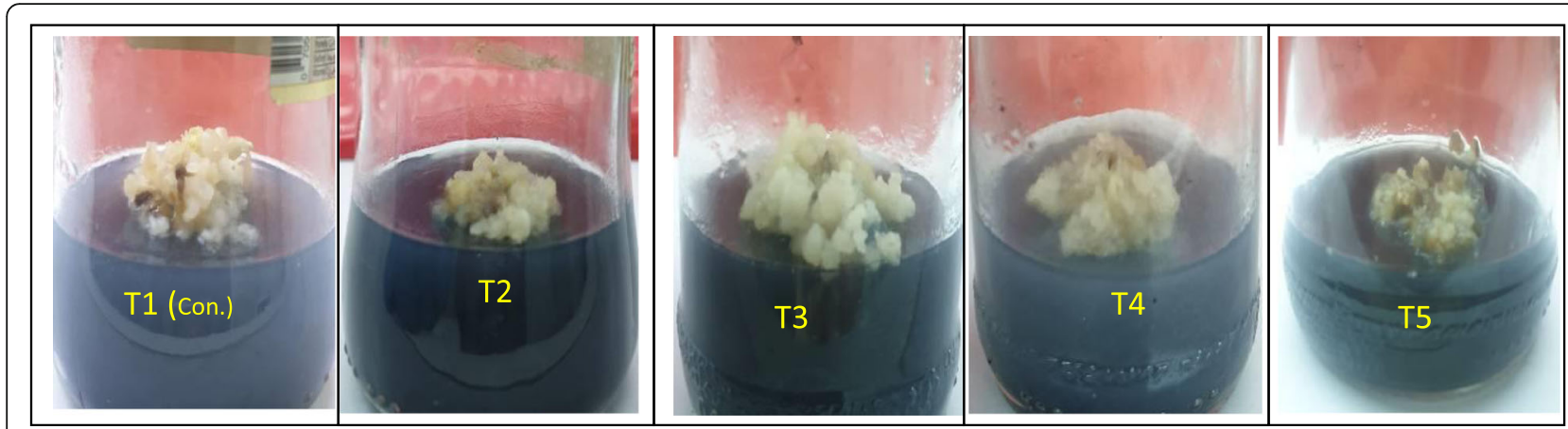

Fig. 1 Callus growth on MS media supplemented with chelated iron sources after 12-week treatment (T1) $36.7 \mathrm{mg} \mathrm{L}^{-1} \mathrm{FeEDTA}\left(5.6 \mathrm{mg} \mathrm{L}^{-1} \mathrm{Fe}\right)$ (control), (T2) $73.4 \mathrm{mg} \mathrm{L}^{-1}$ FeEDTA (11.2 $\mathrm{mg} \mathrm{L}^{-1} \mathrm{Fe}$ ), (T3) $93.5 \mathrm{mg} \mathrm{L}^{-1}$ FeEDDHA (5.6 mg L ${ }^{-1} \mathrm{Fe}$ ), (T4) $187.0 \mathrm{mg} \mathrm{L}^{-1} \mathrm{FeEDDHA}$ (11.2 $\left.\mathrm{mg} \mathrm{L}^{-1} \mathrm{Fe}\right)$, and (T5) $280.5 \mathrm{mg} \mathrm{L}^{-1}$ FeEDDHA (16.8 $\left.\mathrm{mg} \mathrm{L}^{-1} \mathrm{Fe}\right)$

to $73.4 \mathrm{mg} \mathrm{L}^{-1}\left(11.2 \mathrm{mg} \mathrm{L}^{-1} \mathrm{Fe}\right)$. However, the $187.0 \mathrm{mg}$ $\mathrm{L}^{-1}$ FeEDDHA application gave the highest response percentage of shoots producing roots with the highest number of roots (Fig. 4) compared with the other treatments after 6 weeks from shoot culture, while the 280.5 $\mathrm{mg} \mathrm{L}^{-1}$ FeEDDHA application gave the highest length of roots.

\section{Effect of Fe sources on some biochemical traits Mineral content}

The chelated iron source treatment led to significant effects on the accumulation of iron (Fe) in the date palm shoot tissues. Shoots grown in medium supplement with $93.5 \mathrm{mg} \mathrm{L}^{-1}$ FeEDDHA (5.6 $\mathrm{mg} \mathrm{L}^{-1} \mathrm{Fe}$ ) induced significant increases in shoot tissue Fe (24.8\%) when compared with the other treatments (Table 3). No significant effect of chelated iron sources on shoot nutrient content was shown regarding magnesium $(\mathrm{Mg})$, calcium $(\mathrm{Ca})$, as well as boron (B) (Table 3).

\section{Changes in chlorophyll}

The chelated iron source treatment led to significant effects on the accumulation of iron (Fe) in the date palm shoot tissues. Shoots grown in medium supplement with
$280.5 \mathrm{mg} \mathrm{L}^{-1}$ FeEDDHA (16.8 $\mathrm{mg} \mathrm{L}^{-1} \mathrm{Fe}$ ) induced increases in shoot tissue Fe (1.110) when compared with the other treatments (Table 4). No significant effect of chelated iron sources on shoot nutrient content was shown regarding magnesium $(\mathrm{Mg})$, calcium $(\mathrm{Ca})$, as well as boron (B) (Table 4).

\section{Endogenous IAA levels}

Figure 5 shows the effect of FeEDTA and FeEDDHA on endogenous IAA content. Shoots cultured in medium supplement with $187.0 \mathrm{mg} \mathrm{L}^{-1}$ FeEDDHA (11.2 $\mathrm{mg} \mathrm{L}^{-1}$ Fe) showed the highest IAA content $\left(6.10 \mu \mathrm{g} \cdot \mathrm{gm}^{-1}\right)$ which was significantly different than what was reported at the shoots grown in the other media $(p<0.05)$. On the other hand, the lowest contents were recorded in shoots grown in the medium supplemented with FeEDTA at $36.7 \mathrm{mg} \mathrm{L}^{-1}$ (5.6 $\mathrm{mg} \mathrm{L}^{-1} \mathrm{Fe}$ ) (control).

\section{Discussion}

The results showed that iron sources and their concentrations are important factors in propagating the date palm cv. Barhee in vitro. The addition of $93.5 \mathrm{mg} \mathrm{L}^{-1}$ FeEDDHA (5.6 $\mathrm{mg} \mathrm{L}^{-1} \mathrm{Fe}$ ) to MS medium resulted in better growth measured by increased callus weight,

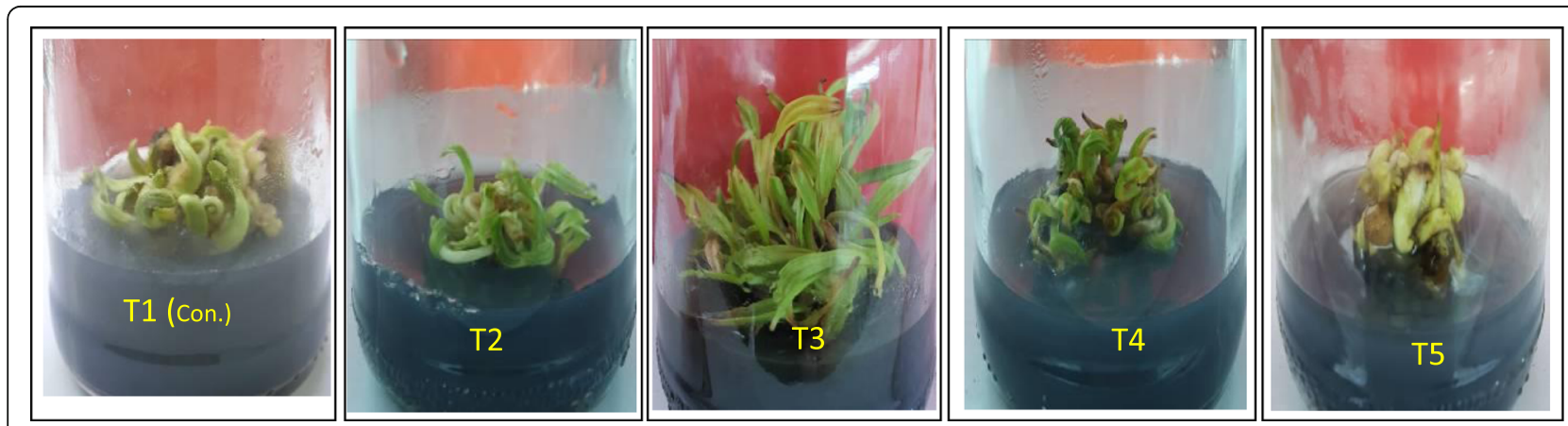

Fig. 2 Bud induction on MS media supplemented with chelated iron sources (T1) $36.7 \mathrm{mg} \mathrm{L}^{-1}$ FeEDTA (5.6 mg $\mathrm{L}^{-1} \mathrm{Fe}$ ) (control), (T2) $73.4 \mathrm{mg} \mathrm{L}{ }^{-1}$ FeEDTA (11.2 mg L-1 Fe), (T3) $93.5 \mathrm{mg} \mathrm{L}^{-1}$ FeEDDHA (5.6 mg L-1 Fe), (T4) $187.0 \mathrm{mg} \mathrm{L}^{-1}$ FeEDDHA (11.2 $\left.\mathrm{mg} \mathrm{L}^{-1} \mathrm{Fe}\right)$, and (T5) $280.5 \mathrm{mg} \mathrm{L}^{-1}$ FeEDDHA (16.8 $\left.\mathrm{mg} \mathrm{L}^{-1} \mathrm{Fe}\right)$ 


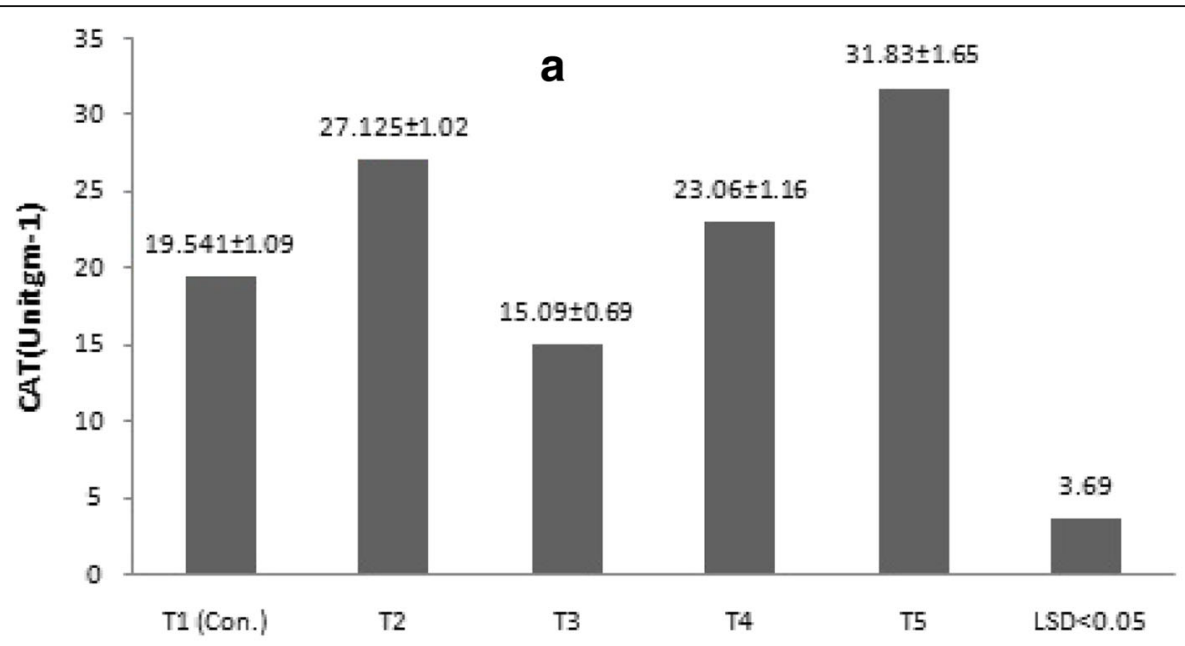

Treatments

b

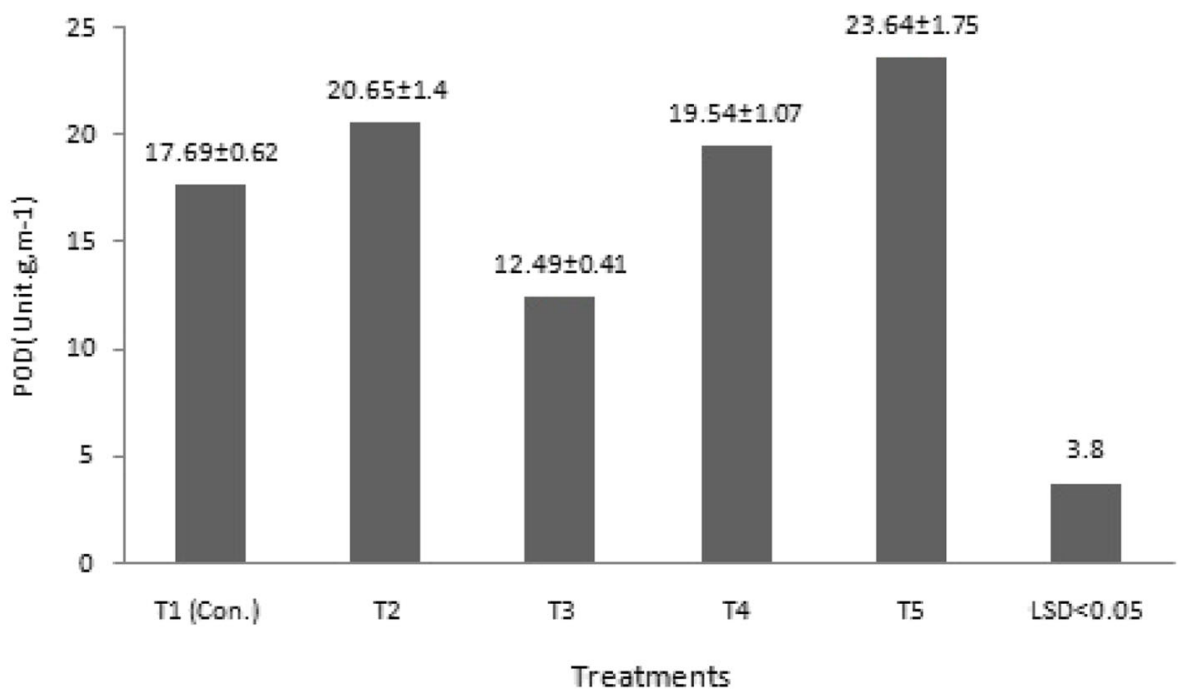

Fig. 3 Effect of chelated iron sources FeEDTA and FeEDDHA on a catalase (CAT) and $\mathbf{b}$ peroxidase (POD) activity in shoots

Table 2 Effect of chelated iron sources FeEDTA and FeEDDHA on in vitro rooting

\begin{tabular}{llll}
\hline Treatments $\left(\mathrm{mg}_{\mathrm{L}}{ }^{-1}\right)$ & Response shoots for root regeneration $(\%)$ & Mean number of roots/shoot & Length $(\mathrm{cm})$ \\
\hline T1 (control) & $66.67 \pm 4.33 \mathrm{~cd}$ & $4.1 \pm 0.39 \mathrm{~b}$ & $1.01 \pm 0.2 \mathrm{~cd}$ \\
T2 & $60.00 \pm 4.90 \mathrm{~d}$ & $3.6 \pm 0.30 \mathrm{bc}$ & $0.90 \pm 0.21 \mathrm{~d}$ \\
T3 & $80.00 \pm 3.89 \mathrm{ab}$ & $5.7 \pm 0.23 \mathrm{a}$ & $2.27 \pm 0.47 \mathrm{~b}$ \\
T4 & $86.67 \pm 6.40 \mathrm{a}$ & $6.1 \pm 0.81 \mathrm{a}$ & $3.90 \pm 0.42 \mathrm{a}$ \\
T5 & $73.34 \pm 3.39 \mathrm{bc}$ & $2.8 \pm 0.25 \mathrm{c}$ & $4.70 \pm 0.23 \mathrm{a}$
\end{tabular}

Means in each column with different letters show significant differences $(P \leq 0.05)$ 


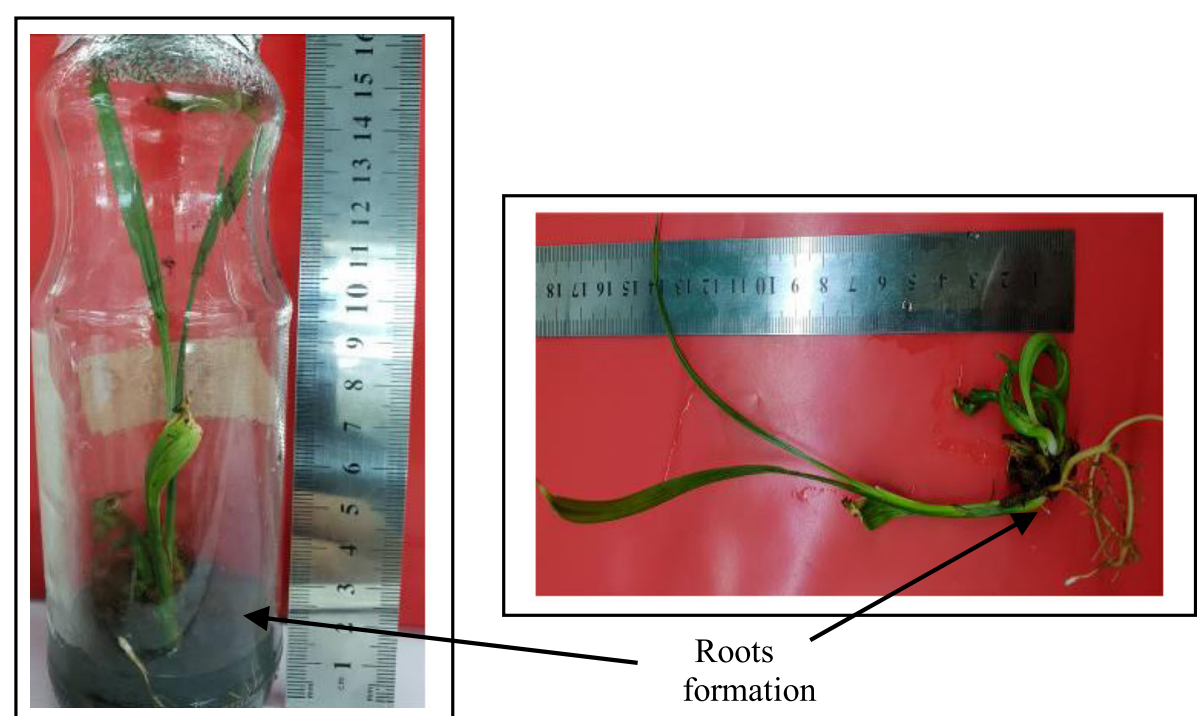

Fig. 4 Rooting of date palm shoot cv. Barhee on MS medium supplemented with $187.0 \mathrm{mg} \mathrm{L}^{-1}$ FeEDDHA (11.2 $\left.\mathrm{mg} \mathrm{L}^{-1} \mathrm{Fe}\right)$, after 45 days from shoot culture on the rooting medium

response percentage, and a number of shoots per jar (220.8 mg, 86.87\%, and 17.3 buds) respectively, which can be recommended for callus growth and shoot multiplication. FeEDTA, typically used as a source of iron in the media, is unstable in light, and iron rapidly becomes unavailable to cultures. More than $75 \%$ of the total iron is consumed by the tissue cultured in the first week of culturing [23]. Although the medium containing FeEDDHA was essential for callus growth and $P$. dactylifera $\mathrm{L}$ propagation, the results showed high concentrations of FeEDDHA-inhibited callus growth, development, and bud proliferation. We observed inhibition of shoot multiplication on culture media equipped with a double and triple concentration of FeEDDHA in growth media (Table 1). Microelement salt concentration can play a significant role in the micropropagation of woody plants $[24,25]$. The addition of FeEDDHA to the culture medium increased the percentage of leaf formation in some red raspberry cultivars and the number of adventitious buds in all five studied cultivars [26]. FeEDDHA beneficial effect on in vitro cultured tissues' high stability is attributed to the high stability of this type of iron chelate, which enables iron to be obtained and maintain a stable ionic balance in the culture medium [27]. In consistency with our experiment results, the beneficial effect of FeEDDHA on adventitious buds induction was confirmed by [28] for many blackberry cultivars. Iron $(\mathrm{Fe})$ is one of the micronutrients; it is essential for plant growth and chlorophyll production. Fe is necessary for many physiological activities like chlorophyll synthesis and biochemical reactions, photosynthesis, respiration, and enzyme activity [7]. The high levels of FeEDDHA showed the maximum CAT and POD activity. The increased activity of CAT and POD in the control treatment and FeEDDHA at high concentrations may be interpreted as an attempt by date palm plants to overcome ROS accumulation under iron deficiency or excess conditions compared to other treatments.

A prerequisite for any method of propagation is the effective rooting of in vitro shoots before their establishment in the soil $[29,30]$. To our knowledge, this is the first study of using Fe-EDDHA on in vitro propagation

Table 3 Effect of chelated iron sources FeEDTA and FeEDDHA on the nutrient content in the shoots of date palm cv. Barhee in vitro

\begin{tabular}{lllll}
\hline Treatments $\left(\mathrm{mg}^{-L^{-1}}\right)$ & $\mathrm{Mg}\left(\mathrm{mg} \mathrm{g}^{-1} \mathrm{DW}.\right)$ & $\mathrm{Ca}\left(\mathrm{mg} \mathrm{g}^{-1} \mathrm{DW}.\right)$ & $\mathrm{B}\left(\mu \mathrm{g}^{-1} \mathrm{DW}\right)$ & $\mathrm{Fe}\left(\mu \mathrm{g}^{-1} \mathrm{DW}\right)$ \\
\hline T1 (control) & $13.174 \pm 0.41 \mathrm{a}$ & $18.619 \pm 0.87 \mathrm{a}$ & $2.088 \pm 0.5 \mathrm{a}$ & $0.298 \pm 0.13 \mathrm{~d}$ \\
T2 & $13.153 \pm 0.50 \mathrm{a}$ & $18.779 \pm 0.88 \mathrm{a}$ & $2.350 \pm 0.4 \mathrm{a}$ & $0.528 \pm 0.08 \mathrm{c}$ \\
T3 & $13.986 \pm 0.95 \mathrm{a}$ & $19.399 \pm 0.52 \mathrm{a}$ & $2.914 \pm 0.3 \mathrm{a}$ & $0.783 \pm 0.06 \mathrm{~b}$ \\
T4 & $14.068 \pm 0.66 \mathrm{a}$ & $19.582 \pm 0.47 \mathrm{a}$ & $3.010 \pm 0.2 \mathrm{a}$ & $1.013 \pm 0.04 \mathrm{a}$ \\
T5 & $13.744 \pm 0.65 \mathrm{a}$ & $18.800 \pm 0.87 \mathrm{a}$ & $2.694 \pm 0.2 \mathrm{a}$ & $1.110 \pm 0.05 \mathrm{a}$ \\
\hline
\end{tabular}

Means in each column with different letters show significant differences $(P \leq 0.05)$ 
Table 4 Effect of chelated iron sources FeEDTA and FeEDDHA on the content of chlorophylls a, b, and total chl in the date palm cv. Barhee in vitro

\begin{tabular}{llll}
\hline Treatments $\left(\mathrm{mg.L}^{-1}\right)$ & $\mathrm{Chl} \mathrm{a}\left(\mathrm{mg} \mathrm{g}^{-1} \mathrm{FW}\right)$ & $\mathrm{Chl} \mathrm{b}\left(\mathrm{mg} \mathrm{g}^{-1} \mathrm{FW}\right)$ & ${\text { Total Chl }\left(\mathrm{mg} \mathrm{g}^{-1} \mathrm{FW}\right)}$ \\
\hline T1 (control) & $0.72 \pm 0.023 \mathrm{~d}$ & $0.099 \pm .004 \mathrm{~d}$ & $0.819 \pm 0.019 \mathrm{~d}$ \\
T2 & $0.92 \pm 0.04 \mathrm{c}$ & $0.130 \pm 0.002 \mathrm{c}$ & $1.05 \pm 0.0016 \mathrm{c}$ \\
T3 & $1.12 \pm 0.07 \mathrm{~b}$ & $0.177 \pm 0.08 \mathrm{~b}$ & $1.297 \pm 0.061 \mathrm{~b}$ \\
T4 & $1.39 \pm 0.10 \mathrm{a}$ & $0.243 \pm 0.003 \mathrm{a}$ & $1.633 \pm 0.08 \mathrm{a}$ \\
T5 & $1.01 \pm 0.06 \mathrm{bc}$ & $0.149 \pm 0.002 \mathrm{c}$ & $1.159 \pm 0.20 \mathrm{bc}$ \\
\hline
\end{tabular}

Means in each column with different letters show significant differences $(P \leq 0.05)$

of date palm, including rooting. However, in other plant species like apple [31], reported that the highest root number in $1 / 2 \mathrm{MS}+0.15 \mathrm{~g} / \mathrm{l} \mathrm{Fe-EDDHA}+2.4 \mathrm{~g} / \mathrm{l}$ thiamin. FeEDDHA stimulating effect on rooting has been reported in many plants, such as Prunus GF-677 and citrus rootstocks [32, 33].

Iron $(\mathrm{Fe})$ is believed to have a role in protein synthesis, root development, and a lack of nitrates in plants that accumulate due to ferredoxin. At the appropriate concentration and the optimal chemical type on in vitro rooting, the effect of iron may be correlated with peroxidase and catalase enzyme activities, which both affect auxin metabolism [34]. FeEDDHA, which is most stable, does not interfere with auxin metabolism and does not produce reactive oxygen species [35]. Altering FeEDTA to FeEDDHA in the medium increases iron availability in many plant species and reduces micronutrient deficiency [36] .

In light of our findings, replacing FeEDTA with FeEDDHA and increasing the concentration of iron ions in the culture medium resulted in better plantlet quality, with an increase in chlorophyll content in shoots in the presence of FeEDDHA.
Iron deficiency inhibits the growth of chloroplasts in plant leaves. It is essential for chlorophyll formation and plant development. This factor is an important part of the energy plants [37]. Shoots grown in a medium supplemented with the Fe-EDDHA had more amount of chlorophyll than Fe-EDTA. These results showed the efficacy of using Fe-EDDHA in culture media to improve the date palm micropropagation efficiency.

Auxin affects a wide range of growth and development processes in the plant, including cell elongation, cell division, and rooting. Auxin is involved in plant organogenesis. EDTA may stimulate IAA action by suppressing its degradation through IAA decarboxylation [38]. Additionally, auxin is one of the essential plant hormone classes for the growth and development of in vitro organs. Under different stress conditions of iron concentrations, endogenous IAA accumulation was higher in $M$. baccata roots at lower levels compared to higher levels [39]. These observations confirm our results that increased cellular auxin levels cause enhanced root formation [40].

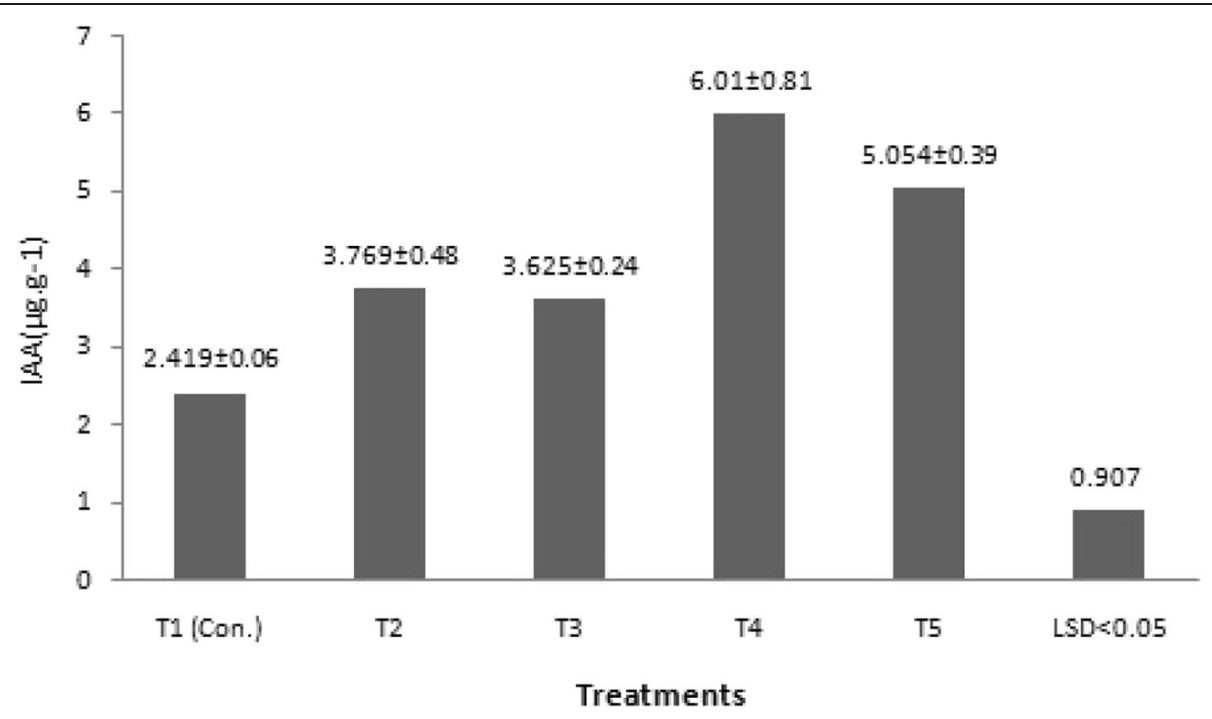

Fig. 5 Effect of chelated iron sources FeEDTA and FeEDDHA on endogenous IAA content 


\section{Conclusion}

Media supplemented with $93.5 \mathrm{mg} \mathrm{L}^{-1}\left(5.6 \mathrm{mg} \mathrm{L}^{-1} \mathrm{Fe}\right)$ FeEDDHA gave the highest callus induction and bud formation. Additionally, CAT and POD activity increased in in vitro shoots regenerated in the same medium mentioned above. Significant increases in rooting percentage and root number were also observed on shoots grown in a medium containing FeEDDHA 187.0 $\mathrm{mg} \mathrm{L}^{-1}\left(11.2 \mathrm{mg} \mathrm{L}^{-1} \mathrm{Fe}\right)$ compared with other treatments. Furthermore, FeEDDHA allows a substantial increase of endogenous hormone levels (IAA) and chlorophyll in shoots. Accordingly, this increase can affect root development in shoots of date palm cv. Barhee. Therefore, we suggest applying MS medium with $93.5 \mathrm{mg} \mathrm{L}^{-1}$ (5.6 $\mathrm{mg} \mathrm{L}^{-1} \mathrm{Fe}$ ) FeEDDHA for the callus and multiplication phase, followed by rooting with 187.0 $\mathrm{mg} \mathrm{L}^{-1}$ (11.2 $\left.\mathrm{mg} \mathrm{L}^{-1} \mathrm{Fe}\right)$.

\section{Abbreviations}

NAA: Naphthaleneacetic acid; IAA: Indoleacetic acid; 2iP: N6-(2-Isopentenyl) adenine; FeEDTA: Ferric ethylenediaminetetraacetic acid;

FeEDDHA: Ethylenediamine di-2-hydroxyphenyl acetate ferric; CAT: Catalase POD: Peroxidase

\section{Acknowledgements}

The author thanks and appreciates all the staff at the Date Palm Research Center, especially in the Date Palm propagation Lab.

\section{Author's contributions}

Al AMW prepared the culture media and the conduct of plant tissue culture of the date palm, and followed the growth and development of cultures. The author also analyzed the physiological characteristics of the tissues and wrote the manuscript. The author read and approved the final manuscript.

\section{Funding}

The work received no funding.

Availability of data and materials

All data generated or analyzed during this study are included in this article.

\section{Declarations}

Ethics approval and consent to participate

Not applicable.

\section{Consent for publication}

Not applicable.

\section{Competing interests}

The author declares that they have no competing interests.

Received: 5 March 2021 Accepted: 4 May 2021

Published online: 01 June 2021

\section{References}

1. Al-Mayahi AMW (2019) Effect of aluminium on the growth of the in vitro culture tissues of the date palm (Phoenix dactylifera L.) cv. Um-Adelhin. Folia Oecol 46(2):164-169. https://doi.org/10.2478/foecol-2019-0019

2. Al-Mayahi AMW, Ahmed AN, Al-khalifa AA (2010) Isolation and diagnose of fungi associated with the cultivation of tissues of five cultivars of date palm (Phoenix dactylifera L.) and the effect of fungicide Benlate in control. Basra J Date Palm Res 9(2):79-97

3. Al-Mayahi AMW (2020) Effect of calcium and boron on growth and development of callus and shoot regeneration of date palm cv. Barhee. Can J Plant Sci. 100(4):357-364
4. Al-Mayahi AMW (2016) Effect of silicon (Si) application on Phoenix dactylifera L. growth under drought stress induced by polyethylene glycol (PEG) in vitro. Amer J Plant Sci. 7:1711-1728

5. Al-Mayahi AMW, Ali AH, Shareef HJ (2018) Influence of cold pretreatment on shoot regeneration from callus in date palm (Phoenix dactylifera L.) CV. 'Barhee'. J Gen Eng Biotech. 16(2):607-612. https://doi.org/10.1016/j.jgeb.201 8.07.002

6. Al-Mayahi AMW, Jafar ON, Mohsen KA (2020) Effect of glutathione (GSH) on date palm (Phoenix dactylifera L.) micropropagation. Folia Oecologica 47(1): 64-69. https://doi.org/10.2478/foecol-2020-0008

7. Jalali M, Zargani M (2014) The impact of nano Fe-chelate, Fe-EDDHA nonnano and FeSO4 on the growth and physiological index in lettuce (Lactuca sativa L.) varieties grown in NFT. J Bio Env Sci. 4(2):434-442

8. Rout GR, Sahoo S (2015) Role of iron in plant growth and metabolism. Rev Agric Sci 3(0):1-24. https://doi.org/10.7831/ras.3.1

9. Kobayashi T, Nishizawa NK (2012) Iron uptake, translocation, and regulation in higher plants. Annu Rev Plant Biol 63(1):131-152. https://doi.org/10.114 6/annurev-arplant-042811-105522

10. Murashige T, Skoog F (1962) A revised medium for rapid growth and bioassays with tobacco tissue cultures. Physiol Plantarum 15(3):473-497. https://doi.org/10.1111/j.1399-3054.1962.tb08052.x

11. Dalton CC, lqbal K, Turver DA (1983) Iron phosphate precipitation in Murashige and Skoog media. Physiol Plant 57(4):472-476. https://doi.org/1 0.1111/j.1399-3054.1983.tb02771.x

12. Lombardi L, Sebastiani L, Vitagliano C (2003) Physiological, biochemical, and molecular effects of in vitro induced iron deficiency in peach rootstock Mr.S 2/5. J Plant Nutr 26(10-11):2149-2163. https://doi.org/10.1 081/PLN-120024271

13. Zawadzka M, Orlikowska T (2009) Influence of FeEDDHA on in vitro rooting and acclimatization of red raspberry (Rubus idaeus L.) in peat and vermiculite. J Horticultural Sci Biotechnol 84(6):599-603

14. Al-Mayahi AMW (2015) An efficient protocol for indirect somatic embryogenesis and shoot organogenesis from leaf segments of date palm (Phoenix dactylifera L.). cv Quntar. Afr J Agric Res. 10(10):1031-1042

15. Cakmak I, Marschner H (1992) Magnesium deficiency and high light intensity enhance activities of superoxide dismutase ascorbate peroxidase, and glutathione reductase in bean leaves. Plant Physiol. 98(4):1222-1227. https://doi.org/10.1104/pp.98.4.1222

16. Maxwell DP, Bateman DF (1967) Changes in the activity of some oxidases in extracts of Rhizoctonia infected bean hypocotyls in relation to lesion maturation. Phytopathology 57:132-136

17. Allam Al, Hollis JP (1972) Sulfide inhibition of oxidase in rice roots. Phytopathology 62(6):634-639. https://doi.org/10.1094/Phyto-62-634

18. Cresser MS, Parsons JW (1979) Sulphuric perchloric acid digestion of plant material for the determination of nitrogen, phosphours, potassium, calcium and magnesium. Anal Chem Acta 109:43-436

19. Jackson ML (1962) Soil chemical analysis. Prentice-Hall Inc, New York, p 498

20. Gaines TP, Mitchell GA (1979) Boron determination in plant tissue by azomethine H method. Commun Soil Sci Plant Anal. 10(8):1099-1108. https://doi.org/10.1080/00103627909366965

21. Porra RJ (2002) The chequered history of the development and use of stimulation quantions for the accurate determination of chlorophylls $A$ and B. Photosynthesis Res. 73(1/3):149-156. https://doi.org/10.1023/A:10204 70224740

22. Nagar PK, Sood S (2006) Changes in endogenous auxins during winter dormancy in tea (Camellia sinensis L.) O. Kuntz. Acta Physiol Plant. 28(2): 165-169

23. Ramage CM, Williams RR (2003) Mineral uptake in tobacco leaf discs during different developmental stages of shoot organogenesis. Plant Cell Rep 21(11):1047-1053. https://doi.org/10.1007/s00299-003-0628-3

24. Andreu P, Marì JA (2005) In vitro culture establishment and multiplication of the Prunus rootstock 'Adesoto 101 ' (P. insititia L.) as affected by the type of propagation of the donor plant and by the culture medium composition. Sci. Hortic. 106(2):258-267. https://doi.org/10.1016/j.scienta.2005.03.008

25. Al-Mayahi AMW (2014) Effect of copper sulphate and cobalt chloride on growth of the in vitro culture tissues for date palm (Phoenix dactylifera L.) cv. Ashgar. Amer J Agri and Bio Sci 9(1):6-18. https://doi.org/10.3844/aja bssp.2014.6.18

26. Zawadzka M, Orlikowska T (2006) Factors modifying regeneration in vitro of adventitious shoots in five red raspberry cultivars. J Fruit Ornam Plant Res 14:105-115 
27. Shibli RA, Mohammad MJ, Ajlouni ZI (2002) Growth and micronutrient acquisition of in vitro-grown bitter almond and sour orange in response to iron concentration from different iron chelates. J Plant Nutr 25(7):15991606. https://doi.org/10.1081/PLN-120005410

28. Tsao CW, Reed BM (2002) Gelling agents, silver nitrate and sequestrene iron influence adventitious shoot and callus formation from Rubus leaves. In Vitro. Cell Devel Bio-Plant 38(1):29-32. https://doi.org/10.1079/IVP2001245

29. Dobránszky J, Teixeira da Silva JA (2010) Micropropagation of apple-a review. Biotechnol Adv 28(4):462-488. https://doi.org/10.1016/j.biotechadv.2 010.02 .008

30. Shareef HJ, Al-Mayahi AMW, Alhamd AD (2016) Effect of desiccation and cold hardening on germination of somatic embryos in date palm (Phoenix dactylifera L.) Berhi cultivar in vitro. Adv.App. Sci Res 7(3):58-64

31. Tabalvandani HM, Yadollahi A, Atashkar D, Kalatejari S, Eftekhari M (2014) Optimized root production during micropropagation of new Iranian apple hybrid rootstock (AZ X M9): effects of Fe-EDDHA and thiamine. Int J Adv Biol Biom Res 2(10):2659-2662

32. Antonopou C, Dimassi K, Therios I, Chatzissavvidis C, Padakis I (2007) The effect of Fe-EDDHA and of ascorbic acid on in vitro rooting of the peach rootstock GF-677 explants. Acta Physio Plant 29(6):559-561. https://doi.org/1 0.1007/s11738-007-0067-9

33. Dimassi K, Chouliaras V, Diamantidis G, Therios I (2003) Effect of iron and auxins on peroxidise activity and rooting performance of three citrus rootstocks in vitro. J Plant Nutr. 26(5):1023-1034. https://doi.org/10.1081/ PLN-120020073

34. Molassiotis AN, Dimassi K, Diamantidis G, Therios I (2004) Changes in peroxidase and catalase activity during in vitro rooting. Biol Plantarum 48(1): 1-5. https://doi.org/10.1023/B:BIOP.0000024267.68394.96

35. Becana M, Moran JF, Iturbe-Ormaetexe I (1998) Iron-dependent oxygen free radical generation in plants subjected to environmental stress: toxicity and antioxidant protection. Plant Soil 201(1):137-147. https://doi.org/10.1023/A:1 004375732137

36. Zawadzka M, Orlikowska T (2006) The influence of FeEDDHA in red raspberry cultures during shoot multiplication and adventitious regeneration from leaf explants. Plant Cell. Tiss Org Cult. 85(2):145-149. https://doi.org/10.1007/s11240-005-9063-1

37. Trejgell A, Libront I, Tretyn A (2012) The effect of Fe-DDHA on shoo multiplication and in vitro rooting of Carlina onopordifolia Besser. Acta Physiol Plant 34:2051-2055

38. Tomaszewski M, Thimann KV (1966) Interactions of phenolic acids, metallic ions and chelating agents on auxin-induced growth. Plant Physiol 41(9): 1443-1454. https://doi.org/10.1104/pp.41.9.1443

39. Han ZH, Han GQ, Xu ZF, Wang Q (2005) Relationship between iron deficiency stress and endogenous hormones in iron-efficient versus inefficient apple genotypes. J Plant Nutr. 28(11):1887-1895. https://doi.org/1 0.1080/01904160500306391

40. Pacheco-Villalobos D, Sankar M, Ljung K, Hardtke CS (2013) Disturbed local auxin homeostasis enhances cellular anisotropy and reveals alternative wiring of auxin-ethylene crosstalk in Brachypodium distachyon seminal roots. Plos Genet. 9(6):e1003564. https://doi.org/10.1371/journal.pgen.1003564

\section{Publisher's Note}

Springer Nature remains neutral with regard to jurisdictional claims in published maps and institutional affiliations.

\section{Submit your manuscript to a SpringerOpen ${ }^{\odot}$ journal and benefit from:}

- Convenient online submission

- Rigorous peer review

- Open access: articles freely available online

- High visibility within the field

- Retaining the copyright to your article

Submit your next manuscript at $\boldsymbol{\nabla}$ springeropen.com 